\title{
UPDATED LIST OF BAT SPECIES POSITIVE FOR RABIES IN BRAZIL
}

\author{
Miriam Martos SODRÉ(1), Adriana Ruckert da GAMA(1) \& Marilene Fernandes de ALMEIDA(1)
}

\begin{abstract}
SUMMARY
This paper presents an updated list of bat species positive for rabies in Brazil. It was developed based on database research via the internet, of international and national literature and annals of the most important technical and scientific meetings related to rabies and chiroptera in Brazil from 1996 to 2009 . The new list of rabies positive bats consists of 41 species, belonging to 25 genera and three families: Phyllostomidae 43.9\%, Vespertilionidae 29.3\% and Molossidae 26.8\%. In addition, questions were raised regarding the lack of data, including sex, age, circumstances and location of bat capture and incomplete and outdated species identification. Results of genetic and antigenic studies performed on Brazilian rabies positive bats were shown.
\end{abstract}

KEYWORDS: Chiroptera; Rabies; South America.

The class Mammalia has 5,416 species and the Order Chiroptera comprises the second largest group of mammals in number, with 1,120 species. Nine families, 64 genera and 167 species of bats live in Brazil $^{53}$. Bats are one of the most important reservoirs and vectors of the rabies virus in the world, according to studies of antigenic and genetic characterization $^{33,46,83}$.

In the United States of America, the first case in humans transmitted by bat was reported in 1951 and according to RUPPRECHT $(2000)^{54}$, it is likely that other cases of human rabies have gone largely unrecognized in the past, because the attention of the health authorities was focused at that time on the widespread distribution of rabies in dogs. Since then, the predominant source of infection in humans shifted from terrestrial animals to insectivorous bats and nowadays, the majority of naturally acquired, indigenous human rabies cases in the United States have resulted from variants of rabies viruses associated with insectivorous bats $^{12}$.

Similarly, in Mexico, two major variants have been identified associated with specific terrestrial hosts and species of bats, Tadarida brasiliensis and the hematophagous bat Desmodus rotundus ${ }^{83}$. In other Latin American countries the two major rabies virus variants identified are the dog and the bat $D$. rotundus. Variants associated with insectivorous bats T. brasiliensis and Lasiurus cinereus have also been identified ${ }^{24,34,47}$.

In Brazil, great progress has been made in the control of the disease in domestic animals mainly as a result of improved canine vaccination programs and other procedures followed in some states, such as educational programs, sterilization and stray animal control. The number of cases had fallen steadily from 1980 , over 170 cases, to under five cases in $2007^{4}$. Genetic and antigenic studies identified variants associated with dogs and the hematophagous bat $D$. rotundus, as well as variants associated with various species of insectivorous bats and species of frugivorous bats of the genus Artibeus, with the variant associated with $D$. rotundus $s^{28,31,33,60}$. D. rotundus has been responsible for outbreaks of rabies in humans in the northern region of Brazil, like those which occurred in 2003 and 2004 in Maranhão and Pará states, involving 64 deaths ${ }^{8,23}$. In this region people live in or near the forest or mangrove ecosystems, their houses are precarious and they are commonly harassed by this bat. Outbreaks of bat-related rabies have been linked to the continued deforestation of the Amazon region, which has displaced vampire bats across northern Brazil and increased contact with humans ${ }^{59}$.

Since great diversity exists among bat species, involving different habits and widespread distribution, knowledge regarding their behavior, population dynamic, shelters in rural and urban areas and the circumstances of capture of positive specimens is essential to developing actions aimed at rabies control in these species. The rabies virus has been isolated from 36 species of bats present in the country ${ }^{17}$. Moreover, observation confirms that 29 species have been exploring refuges in houses and their surroundings ${ }^{77}$ increasing the chance of contact with humans and domestic animals. Among the 863 cases of rabies diagnosed in bats between 2001 and 2007 in Brazil, 424 were non-hematophagous bats (49.1\%), 250 were hematophagous (29\%) and in 189, the species was undetermined $(21.9 \%)^{48}$. However, these data can be underestimated in relation to hematophagous bats because few specimens of Desmodus rotundus have been sent for rabies diagnosis.

Alterations in the environment due to urban and suburban development for the expanding human populations may have reduced both bat roosting 
SODRÉ, M.M.; GAMA, A.R. \& ALMEIDA, M.F. - Updated list of bat species positive for rabies in Brazil. Rev. Inst. Med. Trop. Sao Paulo, 52(2):75-81, 2010.

and foraging habitats. In addition, urban ecosystems offer a large amount of food and shelter associated with a lack of predators, consequently some bat species have adapted to roosting in buildings.

The objective of this study was to present an update of rabies positive bats in Brazil. In addition, questions were raised regarding the lack of data in numerous reports, including sex, age, circumstances and location of capture and incomplete and outdated species identification.

This paper was developed based on database research via the internet of international (PubMed, ScienceDirect and LILACS) and national (SciELO) literature and annals of the most important events related to rabies and chiroptera during the period from 1996 to 2009 (May) using as keywords: rabies, bats, Brazil, chiroptera. This period was selected because the last list of rabies positive bats in Brazil by UIEDA et al. was published in $1996^{80}$.

RUSCHI (1952) $)^{55}$ published the first list of rabies positive bats in 1952, in which 26 species were recorded in Brazil. This work will be launched in a supplementary list, which adds another 15 species (Table 1).

The new list of rabies positive bats consists of 41 species $(24 \%$ of the species already recorded in Brazil), belonging to 25 genera and three families: Phyllostomidae 43.9\%, Vespertilionidae 29.3\% and Molossidae $26.8 \%$. The Phyllostomidae family (frugivorous, hematophagous, nectarivorous, carnivorous, omnivorous and insectivorous) included 15 genera and 18 positive species, followed by Molossidae (insectivorous), with six genera and 11 positive species, while Vespertilionidae (insectivorous) accounted for four genera and 12 rabies positive species (Table 1)

Data showed that the number of positive species from the Phyllostomidae family is higher in relation to Vespertilionidae and Molossidae families which could be explained by the fact that this family comprises the highest number of species in Brazil (90 species); however, $20.0 \%$ of rabies positivity in this group is low compared to the Vespertilionidae (24 species) and Molossidae (26 species) families in which $50.0 \%$ and $42.3 \%$ positivity were recorded, respectively.

The high positivity in these families is probably due the proximity of these animals with the human population. Since species from these bat families use roofs, basements and attics inside human habitations as shelters, citizens complain of their presence and surveillance is more active. In contrast, the majority of the species of the Phyllostomidae family diagnosed as positive live far from urban areas, except for $A$. lituratus, which is commonly observed in almost all urban areas in Brazilian cities.

The hematophagous bat $D$. rotundus is the most frequent positive species in the literature, due its epidemiological importance in the transmission of rabies to herbivores and humans. In this report, the majority $(86.9 \%)$ of specimens were captured in nets near shelters in rural and natural areas.

While this review was being conducted, certain difficulties were observed, such as the lack of data concerning the bats determined as positive for rabies. Sex, age and how the bat was captured were frequently not described. Sometimes only the genus or the feeding preference was mentioned. However, the main problem observed was the use of
Table 1

Updated list of Brazilian bat species positive for rabies

\begin{tabular}{|c|c|}
\hline Species & References \\
\hline \multicolumn{2}{|l|}{ Molossidae } \\
\hline Eumops auripendulus & 21,80 \\
\hline Eumops glaucinus & 21,52 \\
\hline Eumops perotis & 17 \\
\hline Cynomops abrasus & 21,27 \\
\hline Cynomops planirostris & 52 \\
\hline Molossops neglectus & 4 \\
\hline Molossus molossus & $11,15,21,52,57,79,80,82$ \\
\hline Molossus rufus & $21,52,55,58,62,80$ \\
\hline Nyctinomops laticaudatus & $14,19,21,25,44,58,67,79,80$ \\
\hline Nyctinomops macrotis & $21,43,49,79,80$ \\
\hline Tadarida brasiliensis & $11,15,43,57,58,80,81,82$ \\
\hline \multicolumn{2}{|l|}{ Phyllostomidae } \\
\hline Anoura caudifer & 55 \\
\hline Anoura geoffroyi & 55 \\
\hline Artibeus fimbriatus & $20,25,71$ \\
\hline Artibeus lituratus & $\begin{array}{l}11,14,15,19,21,25,32,34,35,43,50,52, \\
58,60,66,72,80,82\end{array}$ \\
\hline Artibeus planirostris & $21,55,60,80$ \\
\hline Carollia perscipillata & $43,78,80,82$ \\
\hline Chrotopterus auritus & 55 \\
\hline Desmodus rotundus & $\begin{array}{l}13,21,22,29,32,43,55,56,58 \\
61,64,68,80,82\end{array}$ \\
\hline Diaemus youngi & 80 \\
\hline Diphylla ecaudata & $16,55,80$ \\
\hline Glossophaga soricina & 55,70 \\
\hline Lonchorrhina aurita & 55 \\
\hline Lophostoma brasiliense & 55 \\
\hline Micronycteris megalotis & 55 \\
\hline Phyllostomus hastatus & 55 \\
\hline Platyrrhinus lineatus & 55,80 \\
\hline Trachops cirrhosus & 80 \\
\hline Uroderma bilobatum & 7 \\
\hline \multicolumn{2}{|l|}{ Vespertilionidae } \\
\hline Eptesicus brasiliensis & 43,65 \\
\hline Eptesicus diminutus & $19,26,65$ \\
\hline Eptesicus furinalis & $3,21,52$ \\
\hline Histiotus velatus & $5,14,42,43,58$ \\
\hline Lasirus blossevillii & $15,41,43,52,55$ \\
\hline Lasiurus cinereus & $11,15,21,43,58$ \\
\hline Lasiurus ega & $14,21,39,43,52,55,58$ \\
\hline Lasiurus egregius & 75 \\
\hline Myotis albescens & 26 \\
\hline Myotis levis & 43 \\
\hline Myotis nigricans & $15,21,25,40,43,52,55,58$ \\
\hline Myotis riparius & 43 \\
\hline
\end{tabular}


outdated species names. Naturally, circumstances occur in which it is difficult to define the species of bat, in such cases, specimens must be sent to an expert.

The most commonly used identification key for Brazilian bat species is VIZOTTO \& TADDEI $(1973)^{84}$; however, several nomenclatures have been subsequently revised in meetings, congresses and relevant papers. The names of some species cited in published papers are listed below; however, these names have been revised, with the current name shown in parenthesis: Dasypterus intermedius (= Lasiurus ega); Molossus ater $(=$ M. rufus); Molossops abrasus (= Cynomops abrasus); Tonatia brasiliense (= Lophostoma brasiliense); Artibeus jamaicensis (= A. planirostris); and Lasiurus borealis $(=$ L. blossevillii)

In 1996, UIEDA et al. ${ }^{80}$ mentioned the new names of Dasypterus intermedius and Molossus ater. Cynomops was considered a subgenus of Molossops until it was recognized as a genus by BARQUEZ et al.(1999) ${ }^{9}$, GREGORIN (2000) ${ }^{30}$ and PETERS et al. $(1999)^{51}$.

Until recently, species of the genus Lophostoma were included in the genus Tonatia; however, LEE Jr. et al. $(2002)^{36}$ showed that these species did not correspond as a monophyletic taxon. The name was altered to Lophostoma and only the species T. bidens and T. saurophila remained in the genus Tonatia ${ }^{53}$.

Regarding A. jamaicensis and A. planirostris, significant controversy exists among taxonomists. Some authors consider A. planirostris as a subspecies and others as a different species. In this work, it has been recognized as a distinct species, in agreement with LIM $(1997)^{38}$, who reported that the distribution of A. planirostris ranges from the Amazon Basin (South of Orinoco) to southern South America, while A. jamaicensis is restricted to northern South America (North of the Orinoco) and Central America.

Lasiurus blossevillii is similar to L. borealis and for a long time the terms were used interchangeably. However, genetic studies by BAKER et al. (1998) ${ }^{6}$ and MORALES \& BICKHAM $(1995)^{45}$ indicated that they are different species. L. borealis is restricted to the Central West, including Canada, the USA and northeastern Mexico, while specimens found south of this geographic limit would be included in L. blossevillii.

Regarding the circumstances of locating positive bats, observation showed that $52.59 \%$ of the bats were found in atypical situations, such as on the ground, including one report of $D$. rotundus in a residential garden in an urban area ${ }^{29}$, inside houses $(11.34 \%)$ and hanging in buildings $(8.24 \%)$. Two cases of positive colonies captured while roosting in roofs $(1.03 \%)$ were reported, but the first specimens of these colonies were captured on the ground, leading to the location of the shelter ${ }^{3,43}$.

The exception in relation to the circumstances of capture are hematophagous bats captured in shelters $(21.65 \%)$, due to the specific kind of surveillance focused on this species in Brazil: 19 reports of $D$. rotundus, one report of $D$. ecaudata and one of D. youngi. One $D$. rotundus was captured while feeding on a human ${ }^{68}(1.03 \%)$. The remaining $4.12 \%$ represents other interesting cases, such as Carollia perspicillata captured during a bat survey of $D$. rotundus in a region of the State of Goiás that did not present symptomatic characteristics for the disease ${ }^{78}$, one Histiotus velatus ${ }^{5}$ and one Chrotopterus auritus ${ }^{69}$, both captured in caves and one Myotis nigricans captured during flight by a child ${ }^{40}$.

According to RUPPRECHT (2000) $)^{54}$, a significant proportion of sick bats discovered by the citizens are rabid. The prevalence of rabies among obviously ill bats submitted by the citizens to health department laboratories typically ranges from $3 \%$ to $15 \%$. Samples of mostly healthy bats captured during flight suggest the prevalence of rabies is less than $1 \%$. Thus, effective public health media that communicate the message not to handle any dead or live bats regardless of appearance or circumstances is still required.

Minnesota residents (U.S.A.) who submitted bats to the Department of Health for rabies testing in 2003 were surveyed by telephone regarding the circumstances of the bat encounter and their knowledge of bats and rabies. While most people submitting bats for rabies testing were aware that bats could carry rabies, few knew they should submit the bat for testing ${ }^{37}$. In the Center for Zoonosis Control in the State of São Paulo (Centro de Controle de Zoonoses, CCZ-SP), despite more than 20 years transmitting information concerning bats and rabies to citizens who complain about their presence, because of the noise, the smell of their urine and the excrement they produce, the staff of the Chiropteran Section have observed that the ecological role of these animals remains largely unknown and much so-called information is based on prejudice, fear and erroneous concepts.

In southeastern Brazil, particularly the state of São Paulo, the largest number of bats identified as rabies positive was reported (38 reports), and data were published regarding these facts. In contrast, only four reports from northern states ${ }^{7,56,64,80}$, five from northeastern states ${ }^{16,22,33,61,80}$ five from states in the Western-Central region ${ }^{25,33,44,56,78}$ and three reports from southwestern states ${ }^{5,11,80}$ were found during the research. It is highly likely that these results are underestimated due to the limited number of published reports concerning positive bats in these regions of the country.

Considering the positive cases reported in São Paulo State, the most common species found with rabies were the frugivorous bat $A$. lituratus and the insectivorous bat $M$. nigricans. According to CUNHA et al (2006) ${ }^{21}$ the highest proportion $(33.7 \%)$ of rabies virus was found in A. lituratus in the period from 1997 to 2002 in bats from 235 towns in the north and northwestern areas of the state. QUEIROZ et al. (2009) ${ }^{52}$ reported that both the A. lituratus and the $M$. nigricans represented $30 \%$ of the bats diagnosed as positive in the northwestern region of São Paulo State, from 1993 to 2007. The genera Artibeus and Myotis represented, respectively, $40.2 \%$ and $18.3 \%$ of the bats tested for rabies from 261 municipalities in the period between April 2002 and November $2003^{58}$. These two species were also the most common rabies positive species according to MARTORELLI $e t$ al. $(2009)^{43}$, each representing $17.6 \%$ in the period 1988 to 2009.

Among the few papers ${ }^{11,14,17,20,21,25,43,52,62,66,67,70,78,79,81,82}$ reporting the sex of rabies positive bats, 47 were female: 13 belonging to Molossidae, 23 to Vespertilionidae and $11 \mathrm{~A}$. lituratus of the Phyllostomidae family; 43 were male belonging to Molossidae (13), Vespertilionidae (14) and Phyllostomidae (16). CUNHA et al (2006) ${ }^{21}$ reported 68 positive bats, 33 females and 35 males, but species were not shown.

Regarding bat age, reports are also scarce $20,21,25,43,66,67,70,78,82$. The majority were adults (88\%) belonging to Molossidae (7), Vespertilionidae 
Table 2

Antigenic rabies studies performed with Brazilian bat samples

\begin{tabular}{|c|c|c|c|}
\hline Reactivity profiles (N-Mabs) & $\mathrm{AgV}^{*}$ & References & Bat species in which the reaction patterns were detected \\
\hline $\mathrm{AgV} \mathrm{C} 12+$ & $\mathrm{NC}$ & $26,28,42$ & Histiotus velatus \\
\hline $\mathrm{AgV} \mathrm{C} 4+\mathrm{C} 10+\mathrm{C} 12+\mathrm{C} 18+\mathrm{C} 19+$ & $\mathrm{NC}$ & 17,28 & Nyctinomops macrotis, Nyctinomops laticaudatus \\
\hline $\mathrm{AgV} \mathrm{C} 4+\mathrm{C} 10+\mathrm{C} 12+$ & $\mathrm{NC}$ & $3,17,28,63,86$ & $\begin{array}{l}\text { Eptesicus furinalis, Eumops auripendulus, E. perotis, E. glaucinus, } \\
\text { N. laticaudatus, Eptesicus sp., Myotis nigricans, Histiotus sp. }\end{array}$ \\
\hline $\mathrm{AgV} \mathrm{C} 4+\mathrm{C} 10+\mathrm{C} 19+$ & $\mathrm{NC}$ & 17,28 & N. laticaudatus \\
\hline $\mathrm{AgV} \mathrm{C} 4+\mathrm{C} 9+\mathrm{C} 10+\mathrm{C} 12+\mathrm{C} 19+$ & 3 & $2,14,17,63,86$ & $\begin{array}{l}\text { Artibeus lituratus, A. planirostris**, A. fimbriatus, Diphylla ecaudata, } \\
\text { Desmodus rotundus, Molossus molossus, M. rufus, Lasiurus ega, } \\
\text { Myotis sp. }\end{array}$ \\
\hline $\mathrm{AgV} \mathrm{C} 4+\mathrm{C} 9+\mathrm{C} 10+\mathrm{C} 12+$ & 4 & $2,17,63,86$ & $\begin{array}{l}\text { Tadarida brasiliensis, M. nigricans, E. furinalis, M. molossus, } \\
\text { Lasiurus sp. }\end{array}$ \\
\hline $\mathrm{AgV} \mathrm{C} 4+\mathrm{C} 9+\mathrm{C} 10+$ & $\mathrm{NC}$ & 28,63 & Lasiurus blossevillii**; Myotis albescens, M. molossus \\
\hline $\mathrm{AgV} \mathrm{C} 1 \pm \mathrm{C} 4+\mathrm{C} 9+\mathrm{C} 10+\mathrm{C} 12+$ & 6 & 17 & Lasiurus cinereus \\
\hline $\mathrm{AgV} \mathrm{C} 4+\mathrm{C} 10+$ & $\mathrm{NC}$ & 86 & Histiotus sp. \\
\hline $\begin{array}{l}\mathrm{AgV} \mathrm{C} 1+\mathrm{C} 4+\mathrm{C} 9+\mathrm{C} 10+\mathrm{C} 12+\mathrm{C} 15+ \\
\mathrm{C} 18+\mathrm{C} 19+\end{array}$ & $\mathrm{NC}$ & 7 & Uroderma bilobatum \\
\hline
\end{tabular}

*Not Compatible; **Artibeus jamaicensis and Lasiurus borealis - outdated name

(7) and Phyllostomidae (8). Only three specimens were identified as young, two of them captured in their shelter ${ }^{20}$ and another found on a sidewalk $^{24}$.

This information can be important due to the fact that some species of bats live in colonies with females forming maternal colonies where males are segregated, thus females have more corporal contact than males. On the other hand, in some species males compete for the highest positions in the hierarchy against females. These circumstances could provoke rabies transmission. Rabies transmission by milk, the transplacental route and prenatal infection are described in the literature ${ }^{18,73,74}$. The bat's age could be important to know if this type of transmission is occurring. Only with reports of these data will be possible to accumulate knowledge to establish their importance in the epidemiological rabies cycle.

Tables 2 and 3 show the antigenic and genetic studies performed on Brazilian bat samples. According to these studies, all the samples investigated were genotype 1 and indicated that the rabies virus can be transmitted between domestic animals and bats ${ }^{28}$. These results suggest that there is considerable diversity among Brazilian bat rabies virus variants, that some of these rabies virus variants may be associated with bats from other countries and further suggest a possibility that speciesspecific viral variants exist among the Brazilian bat rabies virus ${ }^{32,33}$. These findings showed that rabies virus variants exhibit epidemiological characteristics that are reflected in aspects of the ecology of the reservoir bats, such as migratory patterns and range $\mathrm{e}^{33}$.

While these studies are important to understand the epidemiology of rabies, they only covered a few isolated areas of Brazil. Considering the large number of bat species in Brazil, the territorial extension of rabies virus circulation in the country and the low number of isolates analyzed, it is currently difficult to establish the intraspecies and interspecies relations
Table 3

Genetic rabies studies performed on Brazilian bat samples

\begin{tabular}{|c|c|c|}
\hline Variant Host & References & $\begin{array}{l}\text { Bat species in which } \\
\text { the variant host was } \\
\text { detected }\end{array}$ \\
\hline Desmodus rotundus & 32 & Molossus rufus \\
\hline Desmodus rotundus & $32,33,60$ & Artibeus lituratus \\
\hline Desmodus rotundus & 32,60 & Artibeus planirostris \\
\hline $\begin{array}{l}\text { Desmodus rotundus/ } \\
\text { Eptesicus spp }\end{array}$ & 32 & Eumops auripendulus \\
\hline Desmodus rotundus & 7 & Uroderma bilobatum \\
\hline Eptesicus spp & 32,33 & Eptesicus furinalis \\
\hline Molossus spp & $10,32,33$ & Molossus molossus \\
\hline Molossus spp & 32 & Cynomops abrasus \\
\hline Desmodus rotundus & $10,31,32,33,60$ & Desmodus rotundus \\
\hline $\begin{array}{l}\text { Nyctinomops spp/ } \\
\text { Eptesicus spp. }\end{array}$ & 32,33 & $\begin{array}{l}\text { Nyctinomops } \\
\text { laticaudatus }\end{array}$ \\
\hline Histiotus velatus & 10 & Histiotus velatus \\
\hline
\end{tabular}

of this virus. Thus, more extensive epidemiological studies are required to clarify the complexity of the epidemiological cycles involving rabies infection and bats.

Moreover, bats play an important ecological role in the control of insects, which can cause an impact on agriculture and urban areas, and as pollinators and seed dispersal agents ${ }^{76,85}$. The guano that bats produce is 
a valuable fertilizer in both natural and agricultural systems. In addition, the guano is the basis of the food chain in cave habitats, which makes possible the survival of a large number of parasites species that serve as food for animals at other levels in the food chain ${ }^{1}$.

With the identification of an increasing number of bats presenting this zoonosis in urban areas, the controversy about risk of social interaction between bats and humans is growing. Only further studies that clarify the zoonotic profile of these animals can control or prevent, and adequate measures can be established, with the consequent transmission of relevant information that can guide the population to coexist harmoniously with bat populations.

\section{RESUMO}

\section{Lista atualizada das espécies de morcegos positivas para raiva no Brasil}

Esse artigo apresenta uma lista atualizada de espécies positivas para raiva no Brasil e foi desenvolvida a partir da base de dados na internet da literatura nacional, internacional e dos anais das mais importantes reuniões técnicas e científicas, envolvendo raiva e morcegos no Brasil durante o período de 1996 a 2009. A nova lista de morcegos positivos para raiva consiste de 41 espécies, pertencentes a 25 gêneros e três famílias: Phyllostomidae $43.9 \%$, Vespertilionidae $29.3 \%$ e Molossidae 26.8\%. Também foram discutidas questões como a falta de dados sobre sexo, faixa etária e circunstâncias de captura dos animais e identificação incompleta ou desatualizada das espécies. Resultados dos estudos genéticos e antigênicos realizados em amostras de morcegos brasileiros positivos para raiva foram apresentados.

\section{REFERENCES}

1. Aguiar LMS,\& Taddei VA. Lista das espécies de morcegos brasileiros. Chiropt Neotrop. 1995;1:25-6.

2. Albas A, Souza EAN, Lourenço RA, Favoretto SR, Sodré MM. Perfil antigênico do vírus da raiva isolado de diferentes espécies de morcegos não hematófagos da Região de Presidente Prudente, Estado de São Paulo. Rev Soc Bras Med Trop. 2009;42:15-7.

3. Almeida MF, Favoretto SR, Amatuzzi E, Martorelli LFA; Trezza Neto J; Campos, ACA, et al. Rabies virus isolated from bat colony of insectivorous bats, Eptesicus furinalis - Virus characterization and epidemiological study. In: $16^{\text {th }}$ International Meeting on Research Advances and Rabies Control in the Americas, Ottawa; 2005. p.46-7.

4. Amatuzzi E, Martorelli LFA, Trezza-Netto J, Oliveira ML, Almeida MF. Circulação do Vírus da Raiva em morcegos do Município de São Paulo. In: $9^{\circ}$ Congresso Paulista de Saúde Pública, São Paulo; 2005. Anais. p. 5.

5. Amorim AF, Silva RA, Silva MM. Isolamento do vírus rábico de morcego insetívoro Histiotus velatus, capturado no Estado de Santa Catarina. Pesq Agrop Bras. 1970;5:433-5.

6. Baker RJ, Patton JC, Genoways HH, Bickham JC. Genetic studies of Lasiurus (Chiroptera: Vespertilionidae). Occasional papers the Museum Texas Tech University. 1998;117:115 .

7. Barbosa TF, Travassos Da Rosa ES, Medeiros DBA, Casseb LMN, Pereira AS, Begot $\mathrm{AL}$, et al. Epidemiologia molecular do virus da raiva no Estado do Pará no período de 2000 a 2005: emergência e transmissão por morcegos hematófagos (Desmodus rotundus). Cad Saude Colet (Rio J.). 2007;15:329-48.
8. Barbosa TF, Medeiros DB, Travassos Da Rosa ES, Casseb LMN, Medeiro R, Pereira AS, et al. Molecular epidemiology of rabies virus isolated from different sources during a bat-transmitted human outbreak occurring in Augusto Correa municipality, Brazilian Amazon. Virology. 2008;370:228-36.

9. Barquez RM, Mares MA, Braun JK. The bats of Argentina. Special Publication Museum of Texas Tech and University. 1999;42:1-275.

10. Bernardi F, Nadin-Davis SA, Wandeler AI, Armstrong J, Gomes AAB, Lima FS, et al. Antigenic and genetic characterization of rabies viruses isolated from domestic an wild animals of Brazil identifies the hoary fox as a rabies reservoir. J Gen Virol. 2005;86:3153-62.

11. Bianconi GV, Carneiro D, Guerra PA, Fellini A. A raiva em morcegos urbanos no Estado do Paraná, Brasil. In: $3^{\circ}$ Congresso Brasileiro de Mastozoologia, Aracruz; 2005. Anais. p. 68.

12. Blanton JD, Hanlon CA, Rupprecht CE. Rabies surveillance in the United States during 2006. J Am Vet Med Ass. 2007;231:540-56

13. Bordignon J, Brasil-Dos-Anjos G, Bueno CR, Salvatiera-Oporto J, Dávila AMR, Grisard EC, et al. Detection and characterization of rabies virus in Southern Brazil by PCR amplification and sequencing of the nucleoprotein gene. Arch Virol. 2005;150:695708 .

14. Busolotti AS, Araujo APMT, Ramos MCA, Gomes VAAG, Gama FEN, Cavalieri MO, et al. Rabia en murciélago en la area urbana de Belo Horizonte, Minas Gerais, Brasil: identificación de especies y estudios antigénicos. In: $17^{\text {th }}$ Annual Rabies in the Americas Conference, Brasília; 2006. p. 114.

15. Carrieri ML, Canello FM, Kotait I. Rabies virus isolated from bats in north region of São Paulo state. In: $14^{\text {th }}$ International Conference Rabies in the Americas, Philadelphia; 2003. p. 19-24.

16. Castilho JG, Cavalcante R, Santana AA, Rosa WLG, Carrieri ML, Kotait I. Rabia en murciélago hematófago Diphyla ecaudata y Desmodus rotundus en el Estado de Piauí, Nordeste del Brasil. In: $17^{\text {th }}$ Annual Rabies in the Americas Conference, Brasília; 2006. p. 110.

17. Castilho JG, Canello FM, Scheffer KC, Achkar SM, Carrieri ML, Kotait I. Antigenic and genetic characterization of the first rabies virus isolated from the bat Eumops perotis in Brazil. Rev Inst Med Trop Sao Paulo. 2008;50:95-9.

18. Constantine DG, Tierkel ES, Kleckner MD, Hawkine DM. Rabies in New Mexico caverns bats. Pub Health Rep. 1968;83:303-16.

19. Cunha EMS, Souza MCC, Achkar S, Silva MMS. Detection of rabies virus in non hematophagous bats from São José do Rio Preto, SP, Brazil. In: $9^{\text {th }}$ International Meeting on Research Advances and Rabies Control in the Americas, Puerto Vallarta; 1998. p. 8-12.

20. Cunha EMS, Lara MCCSH, Nassar AFC, Sodré MM, Amaral LFV. Isolation of rabies virus in Artibeus fimbriatus bat in the State of Sao Paulo, Brazil. Rev Saúde Públ. 2005;39:683-4.

21. Cunha EMS, Silva LHQ, Lara MCCSH, Nassar AFC, Albas A, Sodré MM, et al. Bat rabies in the north-northwestern regions of the State of São Paulo, Brazil: 1997-2002. Rev Saúde Públ. 2006;40:1082-6.

22. Dantas-Torres F, Valença LA, Andrade-Filho GV. First record of Desmodus rotundus in urban area from the city of Olinda, Pernambuco, Northeastern Brazil: a case report. Rev Inst Med Trop Sao Paulo. 2005;47:107-8.

23. Da Rosa ES, Kotait I, Barbosa TF, Carrieri ML, Brandão PE, Pinheiro AS, et al. Bat-transmitted human rabies outbreaks, Brazilian Amazon. Emerg Infect Dis. 2006;12:1197-1202.

24. De Mattos CA, Favi CM, Yung PV, Pavletic BC, De Mattos CC. Bat rabies in urban centers in Chile. J Wildl Dis. 2000;36:231-40. 
25. Deus GT, Becer M, Navarro IT. Diagnóstico de raiva em morcego não-hematófago na cidade de Campo Grande, Mato Grosso do Sul, Centro-oeste do Brasil: descrição de casos. Cienc Agrar (Londrina). 2003;24:171-6.

26. Favoretto SR, Mattos CC, Carrieri ML, Mattos CA, Cunha EMS, Aguiar EAC, et al. Rabies in Chiroptera: Typification and Epidemiological Study. In: $10^{\text {th }}$ International Meeting on Research Advances and Rabies Control in the Americas, San Diego; 1999. p. 14-9.

27. Favoretto SR, Mattos CC, Carrieri ML, Mattos CA, Cunha EMS, Aguiar EAC, et al. Caracterização de variantes no Brasil e países vizinhos. In: Seminário Internacional de Raiva, São Paulo; 2000. Anais. p. 22-4.

28. Favoretto SR, Carrieri ML, Cunha EMS, Aguiar EAC, Silva LHQ, Sodré MM, et al. Antigenic typing of Brazilian rabies virus samples isolated from animals and humans, 1989-2000. Rev Inst Med Trop Sao Paulo. 2002;44:91-5

29. Ferraz C, Achkar SM, Kotait I. First report of rabies in vampire bats (Desmodus rotundus) in an urban area, Ubatuba, São Paulo State, Brazil. Rev Inst Med Trop Sao Paulo. 2007;49:389-90.

30. Gregorin R. Filogenia de Molossidae Gervais, 1855 (Mammalia; Chiroptera). [Dissertação: Instituto de Biociências]. São Paulo: Universidade de São Paulo; 2000.

31. Ito M, Arai YT, Itou T, Sakai T, Ito FH, Takasaki T, et al. Genetic characterization and geographic distribution on rabies virus isolates in Brazil: identification of two reservoir, dogs and vampire bats. Virology. 2001;284:214-22.

32. Kobayashi Y, Sato G, Shoji Y, Sato T, Itou T, Cunha EMS, et al. Molecular epidemiological analysis of bat rabies viruses in Brazil. J Vet Med Sci. 2005;67:647-52.

33. Kobayashi Y, Sato G, Kato M, Itou T, Cunha EMS, Silva MV, et al. Genetic diversity of bat rabies viruses in Brazil. Arch Virol. 2007;152:1995-2004.

34. Kotait I, Harmani NMS, Favoretto SRL, Carrieri ML, Sodré MM, Panachão MRI, et al. Manejo de quirópteros em foco de raiva em áreas urbanas. In: Seminário Internacional de Raiva, São Paulo; 2000. Anais. p. 22-24

35. Langoni H, Lima K, Menozzi BD, Silva RC. Rabies in the big fruit-eating bat Artibeus lituratus from Botucatu, Southeastern Brazil. J Venom Anim Toxins Trop Dis. 2005;11:84-7.

36. Lee JR TE, Hoofer SR, Van Den Bussche RA, Cook JA. Molecular phylogenetics and taxonomic revision of genus Tonatia (Chiroptera: Phyllostomidae). J Mammal. 2002;83:49-57

37. Liesener AL, Smith KE, Davis RD, Bender JD, Danila RN, Neitzel DF, et al. Circumstances of bat encounters and knowledge of rabies among Minnesota residents submitting bats for rabies testing. Vector Borne Zoonotic Dis. 2006;6:208-15.

38. Lim BK. Morphometric differentiation and species status of the allopatric fruit-eating bats Artibeus jamaicensis and A. planirostris in Venezuela. Studies Neotrop Fauna Environ. 1997;32:65-71.

39. Lino AMCDB, Bichiato PA, Petroni JRC, Mello FCC, Takaoka NY, Reichmann MLAB. Raiva animal no Município de Cotia, São Paulo: relatos de casos. In: $35^{\circ}$ Congresso Brasileiro de Medicina Veterinária, Gramado; 2008. Anais. Avaliable from: www. sovergs.com.br/conbravet2008/anais/cd/resumos/R1139-1.html.

40. Martorelli LFA, Almeida MF, Aguiar EAC, Silva MMS, Novaes ECR. Isolamento do vírus rábico de morcego insetívoro Myotis nigricans. Rev Saúde Públ. 1995;29:140-1.

41. Martorelli LFA, Aguiar EAC, Almeida MF, Silva MMS, Nunes VFP. Isolamento do vírus rábico de morcego insetívoro Lasiurus borealis. Rev Saúde Públ. 1996;30:101-2.

42. Martorelli LFA, Almeida MF, Aguiar EAC, Silva MMS, Durigon EL. Rabies in a bat colony of Histiotus velatus, São Paulo City, Brazil. In: $13^{\text {th }}$ International Meeting on Research Advances and Rabies Control in the Americas, Ooxaca; 2002. p. 60-61.
43. Martorelli LFA, Kataoka APAG, Almeida MF, Trezza-Netto J, Sodré MM, Gama AR, et al. Antigenic characterization of rabies virus isolated in bats from cities of São Paulo state, Brazil during 1988 to 2009. In: International Meeting on Research Advances and Rabies Control in the Americas, Quebec; 2009.

44. Massunaga P, Carrieri ML, Favoretto SR, Paranayba K, Kotait I. Rabies in insectivorous bats in urban area of Brasilia, DF. In: $14^{\text {th }}$ National Meeting of Virology, Florianópolis; 2003

45. Morales JC, Bickham JW. Molecular systematics of the genus Lasiurus (Chiroptera: Vespertilionidae) based on restriction-site maps of the mitochondrial ribosomal genes. J. Mammal.1995;76:730-49.

46. Nadin-Davis SA, Huang W, Armstrong J, Casey J, Bahloul C, Tordo N, et al. Antigenic and genetic divergence of rabies viruses from bat species indigenous to Canada. Virus Res. 2001;74:139-56.

47. Páez A, Nũnez C, García C, Bóshell J. Molecular epidemiology of rabies epizootics in Colombia: evidence for human and dog rabies associated with bats. J Gen Virol 2003;84:795-802.

48. Pan-American Health Organization/World Health Organization. 2008. Available from: http://siepi.panaftosa.org.br/anuais.aspx

49. Passos EC, Carrieri ML, Dainovskas E, Camara M, Silva MMS. Isolamento do vírus rábico em morcego insetívoro Nyctinomops macrotis, no município de Diadema, SP (Brasil). Rev Saúde Públ. 1998;32:74-6.

50. Passos EC, Carrieri ML, Silva MMS, Gonçalves MA, Lopes R, Ferreira E, et al. Raiva em morcegos no Estado de São Paulo. In: $3^{\circ}$ Seminário Nacional de Zoonoses e Animais Peçonhentos, Guarapari; 1998. Anais. p. 23-7.

51. Peters SL, Lim BK, Engstrom MD. Systematics of dog-faced bats (Cynomops) based on molecular and morphometrics data. J Mammal. 2002;83:1097-110.

52. Queiroz LH, Carvalho C, Buso DS, Ferrari CIL, Pedro WA. Perfil epidemiológico da raiva na região Noroeste do Estado de São Paulo no período de 1993 a 2007. Rev Soc Bras Med Trop. 2009;42:9-14.

53. Reis NR, Shibatta AO, Peracchi AL, Pedro WA, Lima IP. Sobre os Morcegos Brasileiros In: Reis NR, Peracchi AL, Pedro WA, Lima IP. Morcegos do Brasil. Londrina; 2007. p. 17-25.

54. Rupprecht CE. Evolution of public health recommendations for human rabies prophylaxis after bat exposure in the United States. In: Basgoz N. Rethinking rabies risks sharpening clinical skills for a reemergence threat. Boston: Harvard, Medical School 2000. p. 46.

55. Ruschi A. Morcegos do Estado do Espírito Santo; família Emballonuridae. Chave analítica para os gêneros, espécies e subespécies representadas no E. E. Santo. B Museu Biol Prof Mello Leitão Ser Zool. 1952;10:1-19.

56. Sato G, Kobayashi Y, Shoji Y, Sato T, Itou T, Ito FH, et al. Molecular epidemiology of rabies from Maranhão and surrounding states in the northeastern region of Brazil. Arch Virol. 2006;151:2243-51.

57. Schaefer R, Batista HB, Franco AC, Rijsewijk FA, Roehe PM. Studies on antigenic and genomic properties of Brazilian rabies virus isolates. Vet Microbiol. 2005;107:161-70.

58. Scheffer KC, Carrieri ML, Albas A, Santos HCP, Kotait I, Ito FH. Rabies virus in naturally infected bats in the state of São Paulo, Southeastern Brazil. Rev Saúde Publ. 2007;41:389-95.

59. Schneider MC, Aron J, Santos-Burgoa C, Uieda W, Ruiz-Velazco S. Common vampire bat attacks on humans in a village of the Amazon region of Brazil. Cadern Saúde Públ. 2001:17:1531-36.

60. Shoji Y, Kobayashi Y, Sato G, Itou T, Miura Y, Mikami T, et al. Genetic characterization of rabies viruses isolated from frugivorous bat (Artibeus spp.) in Brazil. J Vet Med Sci. 2004;66:1271-73. 
61. Shoji Y, Kobayashi Y, Sato G, Gomes AAB, Itou T, Ito FH, et al. Genetic and phylogenetic characterization of rabies virus isolates from wildlife and livestock in Paraiba, Brazil. Acta Virol. 2006;50:33-7.

62. Silva LHQ, Cunha EMS, Pedro WA, Cardoso TC, Souza MCC, Ferrari CIL. Isolamento do vírus rábico em Molossus ater (Chiroptera: Molossidae) no Estado de São Paulo. Rev Saúde Públ. 1999;33:626-8.

63. Silva, LHQ, Favoretto, SR, Cunha, SEM, Martorelli, LFA, Pedro WA, Iamamoto, K, et al. Rabies in the northwestern São Paulo state, Brazil: antigenic and genetic characterization of virus isolates. In: XVII Reunião Internacional de Raiva nas Américas, Brasília; 2006. Anais. p. 211.

64. Silva LP, Ramos OS, Xavier SM, Reis JR. Vírus da raiva em quirópteros no município de Anajás, Estado do Pará, Brasil. In: $35^{\circ}$ Congresso Brasileiro de Medicina Veterinária, Gramado; 2008. Anais. p. 19-21. Available from www.sovergs.com.br/conbravet2008/ anais/cd/resumos/R0634-2.html

65. Silva MMS, Oliveira DS. Identificação das espécies de quirópteros enviados ao Centro de Controle de Zoonoses no período de 1988 a 1998. In: $3^{\circ}$ Seminário Nacional de Zoonoses e Animais Peçonhentos, Guarapari; 1998. Anais. (resumo 04)

66. Silva MMS, Gomes LH, Martorelli LFA. Rabies in frugivorous bats (A. lituratus) in São Paulo city, Brasil. In: $11^{\text {th }}$ International Meeting on Research Advances and Rabies Control in the Americas, Lima; 2000. p. 18-21.

67. Silva MV, Xavier SM, Moreira WC, Santos BCP, Esberard CEL. Vírus rábico em morcego Nyctinomops laticaudatus na cidade do Rio de Janeiro, RJ: isolamento, titulação e epidemiologia. Rev Soc Bras Med Trop. 2007;40:479-81.

68. Silva RA, Souza AM, Passos JJ, Alencar AO, Borges IB, Lima AC, et al. A pesquisa do vírus rábico em morcegos no Brasil. Veterinária (Rio de Janeiro).1967;20:105-14.

69. Silva RA, Alencar AO. Isolamento do vírus rábico das glândulas salivares de morcegos carnívoros da espécie Chrotopterus auritus australis (Thomas). Veterinária (Rio de Janeiro). 1968;21:7-10.

70. Sodré MM, Rosa AR, Almeida MF. Rabies in the nectarivorous bat G. soricina (Pallas, 1766) in São Paulo city, Brazil. Chiropt Neotrop. 2007;13:307-8.

71. Souza HC, Almeida GS, Mattos GLM, Dias AVAB, Moreira WC. Manutenção do vírus rábico em zona urbana da cidade do Rio de Janeiro por Artibeus fimbriatus. In: $35^{\circ}$ Congresso Brasileiro de Medicina Veterinária, Gramado; 2008. Anais. p. 19-21. Available from www.sovergs.com.br/conbravet2008/anais/cd/resumos/R0498-1.html

72. Souza MCAM, Matos SN, Braga LC, Silva MMS. Isolamento do vírus da raiva de morcegos frugívoros Artibeus lituratus, no município de Jacareí, situado no Vale do Paraíba, região leste de São Paulo, Brasil. In: $3^{\circ}$ Seminário Nacional de Zoonoses e Animais Peçonhentos, Guarapari; 1998. Anais. p. 23-7.
73. Steece R, Altenbach JS. Prevalence of rabies specific antibodies in the Mexican freetailed bat (Tadarida brasiliensis mexicana) at Lava Cave, New Mexico. J Wildl Dis. 1989;25: 490-96.

74. Steece RS, Calisher CH. Evidence for prenatal transfer of rabies virus in the Mexican free-tailed bat (Tadarida brasiliensis mexicana). J Wildl Dis. 1989;25:329-34

75. Stutz WH, Albuquerque MC, Uieda W, Macedo EM, França CB. Updated list of bat from Uberlândia, State of Minas Gerais, Southeastern Brazil. Chiropt Neotrop. 2004; $10: 188-90$

76. Swier, V.J. - Distribution, roost site selection and food habits of bats in Eastern South Dakota. [MSc. Dissertation, South Dakota State University]. Dakota; 2003.

77. Taddei VA. Sistemática de quirópteros. Bol Inst Pasteur (S. Paulo). 1996;1:3-15.

78. Tomaz LAG, Zortea M, Souza M, Jayme VS. Isolamento do vírus rábico em morcego Carollia perspicillata em Niquelândia, Goiás. Chiropt Neotrop. 2007;13:309-12.

79. Uieda W, Harmani NMS, Silva MMS. Raiva em morcegos insetívoros (Molossidae) do Sudeste do Brasil. Rev Saúde Publ. 1995;29:393-7.

80. Uieda W, Hayashi MM, Gomes LH, Silva MMS. Espécies de quirópteros diagnosticadas com raiva no Brasil. Bol Inst Pasteur (S. Paulo). 1996;1:17-35.

81. Uieda W. Rabies in the insectivorous bat Tadarida brasiliensis in Southeastern Brazil Rev Saúde Publ. 1998;32:484-5.

82. Uieda W, Chaves ME. Bats from Botucatu region, State of São Paulo, Southeastern Brazil, Chiropt Neotrop. 2005;11:224-6.

83. Velasco-Villa A, Orciari LA, Juárez-Islas V, Gómez-Sierra M, Padilla-Medina I, Flisser A, et al. Molecular diversity of rabies viruses associated with bats in Mexico and other countries of the Americas. J Clin Microbiol. 2006:44:1697-710.

84. Vizotto LD, Taddei VA. Chave para determinação de quirópteros brasileiros. Rev Fac Filos Cien Letr S José R Preto Bol Cienc. 1973;1:1-72.

85. Wilson DE. Bats and humans. What good are bats? In: Wilson DE. Bats in questions: the Smithsonian answer book. The Smithsonian Institution; 1997. p. 120-1.

86. Yung V, Favi M, Fernández J. Genetic and antigenic typing of rabies virus in Chile. Brief Report. Arch Virol. 2002;147:2197-205

Received: 28 July 2009

Accepted: 3 February 2010 